\title{
Comparative study of Performance of RCC Multi-Storey Building for Koyna and Bhuj Earthquakes
}

\author{
Atul N.Kolekar ${ }^{1}$, Y.P.Pawar ${ }^{2}$, Dr. C. P. Pise ${ }^{3,}$ D. D. Mohite ${ }^{2}$, S. S. Kadam², \\ C. M. Deshmukh². \\ P.G. Student, Department of Civil Engineering, SKNSCOE, Pandharpur, Maharashtra, India ${ }^{1}$ \\ Assistant Professor, Department of Civil Engineering, SKNSCOE, Pandharpur, Maharashtra, India ${ }^{2}$ \\ Associate Professor and HOD, Department of Civil Engineering, SKNSCOE, Pandharpur, Maharashtra, India ${ }^{3}$
}

\begin{abstract}
The recent history of earthquakes have indicated that if the structures are not properly designed and constructed with required quality may cause great damage to structures. This fact has resulted in to ensure safety against earthquake forces of tall structures hence, there is need to determine seismic responses of such building for designing earthquake resistant structures by carrying seismic analysis of structure. In the present work dynamic analysis of G+12 RC multi-storied framed building considering for Koyna and Bhuj earthquake is carried out by response spectrum analysis and time history analysis and responses of such building are comparatively studied with the help of SAP2000 software. Two time histories (i.e. koyna and Bhuj) have been used to develop different acceptable criteria (base shear, storey displacement, storey drift). From the results it is recommended that time history analysis should be performed as it predicts the structural response more accurately than the response spectrum analysis. Pushover Analysis is also performed for the same building and from results it is found that building is seismically safe.
\end{abstract}

Keywords-SAP2000, Response Spectrum Analysis, Seismic Responses, Time History Analysis,Pushover Analysis.

\section{I.INTRODUCTION}

The process of urbanization has been a common feature throughout the centuries, Globalization and Growth of high rise buildings is the need of current population, earthquakes have the potential for causing the greatest damages to those tall structures. Hence, it is important to take in to account the seismic load for the design of high-rise structure. Earthquakes occurred in recent past, particularly in the state of Gujarat (Bhuj, 2001) have indicated that if the structures are not properly designed and constructed with required quality may cause great damage to structures and also loss of life. Reinforced concrete buildings have been destructed on a very large scale in Bhuj earthquake of Jan $26^{\text {th }}$ 2001, Even though these buildings are analyzed and designed as per IS code. The damages are caused by inconsistent seismic response, irregularity in mass and plan, soft storey and floating column etc. Hence it becomes necessary to determine actual seismic performance of building subjected to seismic forces. Time history analysis gives more realistic behavior of the building. It gives more accurately seismic responses than response spectrum analysis because of it includes material nonlinearity and dynamic nature of earthquake.

Patil A. S. and Kumbhar P. D. [1] analyzed ten storied $\mathrm{RC}$ building considering different seismic intensities and seismic responses of such building are evaluated with the help of SAP2000 software. Five different time histories have been used considering seismic intensities V, VI, VII, VIII, IX and $\mathrm{X}$ for establishment of relationship between seismic intensities and seismic responses. From the study it is recommended that, to ensure safety against earthquake force, analysis of multistoried RC building using Time History method becomes necessary.

Prashanth P. et al. [2] designed multi storey buildings with regular and irregular plan (as per IS 1893) using STAAD Pro and ETABS software separately. From the design results of beams, we may conclude that ETABS gave lesser area of required steel as compared to STAAD Pro. Form the design results of column; since the required steel for the column forces in this particular problem is less than the minimum steel limit of column (i.e., $0.8 \%$ ), the amount of steel calculated by both the software is equal.

Wakchaure M. R. and Ped S. P. [3] studied the effect of masonry walls on high rise building. Linear dynamic analysis on high rise building with different arrangement was carried out. Earthquake time history is applied to the models. The width of strut was calculated by using equivalent strut method. All analysis was carried out by software ETABS. Base shear, storey displacement, story drift 
was calculated and compared for all models. The results showed that infill walls reduce displacements, time period and increases base shear.

Parvathaneni S. and Elavenil S. [4] done the three dimensional RC frames analysis for gravity loads and lateral loads and the response spectrum analysis and time history analysis carried out to evaluate seismic performance of frame. The response spectrum analysis and time-history analysis is done by using ETABS with compatible accelograms, and results obtained from analysis are verified. Nonlinear time history analysis is done for studying the inelastic behavior of the structures.

Bahador et al. [5] studied Multi-storey irregular buildings with 20 stories using software packages ETABS and SAP 2000 for seismic zone V in India. The investigation of dynamic responses of building under actual earthquakes considering ELCENTRO 1949 and CHI-CHI Taiwan 1999 were done. They highlighted the exactness and accuracy of Time History analysis in comparison with the most commonly adopted Response Spectrum Analysis and Equivalent Static Analysis.

N.M.Nikam [20]considered G+15and G+20 storied building with provision of shear wall at different position and pushover analysisis carried out.They found that fundamental time period is increased due to provision of shear wall as well as global stiffness is increases.

MohommadAzoz and AnshulR.Nikhade [21] studied pushover analysis on reinforced concrete structure in which $\mathrm{G}+10$ building was subjected to push in $\mathrm{X}$ direction and push in $\mathrm{Y}$ direction. Analysis was done in sap2000 15.They found that slope of pushover curve is gradually changed with increase of the lateral displacement of the building. From results the concluded that the building considered for analysis not requires retrofitting.

\section{OBJECTIVES}

1. To analyze the RCC multistory building for seismic forces.

2. To evaluate various responses such as base shear, lateral displacement, storey drift etc. of building for Koyna and Bhuj earthquakes.

3. To compare effect of Koyna and Bhuj earthquakes on performance of RCC multistory building.

4. To compare software results with current practices.

5. To investigate material non-linearity behaviour considering plastic analysis.

\section{METHODS OF ANALYSIS:}

\section{A. Equivalent Static Analysis}

All design against seismic loads must consider the dynamic nature of the load. However, for simple regular structures, analysis by equivalent linear static methods is insufficient. This is permitted in most codes of practice for regular, low- to medium-rise buildings. This procedure takes into account the dynamic behavior of building in an approximate manner; it does not require dynamic analysis. The static method is based on the formulation given in IS codes thus it is easiest one and requires less computational efforts. First, the design base shear is computed for the whole building, and it is then distributed along the height of the building. The lateral forces at each floor levels thus obtained are distributed to individual's lateral load resisting elements.[3,5]

\section{B. Response Spectrum Method}

Response spectrum method is the linear dynamic analysis method. In this method the peak structural response can be obtained directly during an earthquake using the earthquake responses (or design) spectrum. It represents the maximum responses of idealized SDOF systems with certain time period and modal damping, during earthquake ground motion. The maximum response curve is plotted for various damping values and against the undamped natural period, and can be represented in terms of maximum relative displacement or maximum relative velocity.[5,9,10,11,15,16]

\section{Time History Method}

Time History method is step by step analysis of the dynamic response of the structure at each time increment when its base is subjected to ground motion time history record. To perform such an analysis a representative earthquake time history is essential for a structure being evaluated. It is used to determine the seismic response of a structure under dynamic loading of considered earthquake.[1, $4,14,18]$

\section{Pushover Analysis}

Pushover analysis is a static non-linear procedure of analysis of building where loading is goes on increasing with certain predefined pattern. The structure is pushed until a collapse mechanism is developed. With increase in magnitude of loads weak links and failure modes of building are found. The pushover analysis is used to get the relation between base shear and roof displacement. I.e. Pushover curve.[20,21,22] 


\section{STRUCTURAL MODELING AND ANALYSIS :}

The G+12 RC multistory framed building considered for analysis to know the realistic behavior during earthquake with the general form of plan shown in fig 1. RC multi-storey framed building is modeled for two time histories i.e. Bhuj and Koyna. Plan dimensions in $\mathrm{X}$ and $\mathrm{Y}$ direction are $20 \mathrm{~m}$ and $20 \mathrm{~m}$ respectively. The buildings are consisting of columns with dimension $600 \mathrm{~mm} \mathrm{x}$
$600 \mathrm{~mm}$ for all stories and beam with dimension $300 \mathrm{~mm} \times 700 \mathrm{~mm}$. the floor slabs are taken as $150 \mathrm{~mm}$ thick. The height of all floors is $3.2 \mathrm{~m}$ and height of plinth is $2 \mathrm{~m}$. soil type is Medium. Modal damping $5 \%$ is assumed with SMRF and $\mathrm{I}=1$. The columns are assumed to be fixed at the base. Material concrete grade is M30 and while steel $\mathrm{Fe} 415$ is used.
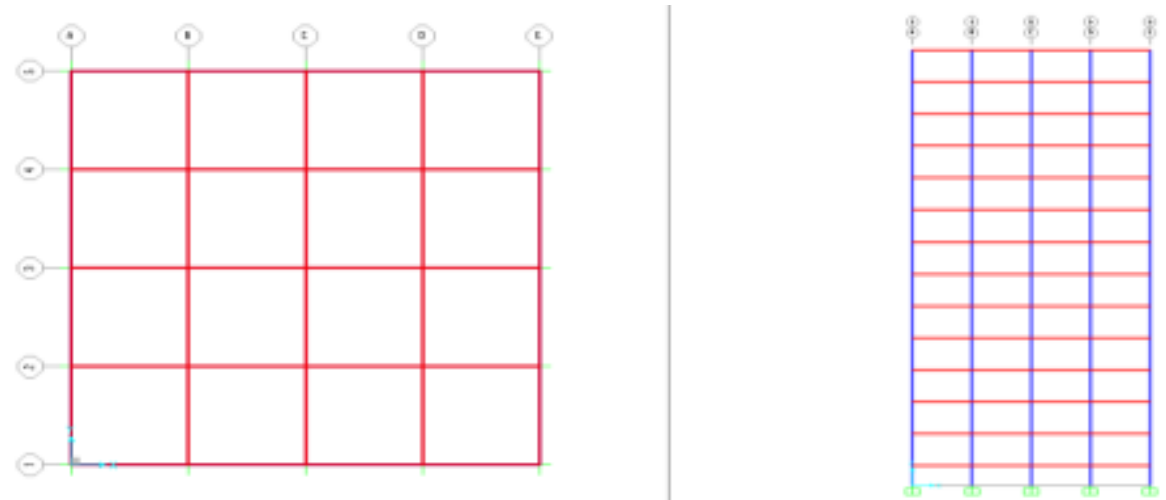

Fig. 1 Plan and Elevation of G+12 RC multistoried framed Building in SAP2000

\section{RESULT AND DISCUSSION:}

The comparative study of storey displacement, base shear and storey drift of building in different stories by response spectrum analysis and time history analysis for
Koyna\&Bhujis performed here. The results obtained from analysis are given below and comparative study is carried out as follows

\section{Comparison of Base Shear:}

Table 1: comparison of story shear for earthquake by RSM and THM

\begin{tabular}{|l|l|l|l|l|}
\hline \multirow{2}{*}{$\begin{array}{l}\text { Story } \\
(\mathrm{mm})\end{array}$} & level & Story shear $(\mathrm{kN})$ & \multicolumn{5}{l|}{} \\
\cline { 2 - 5 } & Koyna-THM & Koyna-RSM & Bhuj-THM & Bhuj-RSM \\
\hline 43600 & 275.137 & 340.344 & 377.016 & 510.517 \\
\hline 40400 & 611.824 & 759.264 & 819.801 & 1138.897 \\
\hline 37200 & 893.170 & 1114.448 & 1283.648 & 1671.674 \\
\hline 34000 & 1254.304 & 1441.154 & 1650.849 & 2116.733 \\
\hline 30800 & 1504.689 & 1654.638 & 1910.848 & 2481.958 \\
\hline 27600 & 1830.732 & 1850.156 & 2022.298 & 2775.235 \\
\hline 24400 & 2138.652 & 2002.965 & 2394.417 & 3004.448 \\
\hline 21200 & 2315.940 & 2118.321 & 2777.447 & 3177.482 \\
\hline 18000 & 2432.479 & 2201.481 & 2968.719 & 3302.222 \\
\hline 14800 & 2508.256 & 2257.701 & 2956.351 & 3386.552 \\
\hline 11600 & 2366.272 & 2292.238 & 2818.154 & 3438.357 \\
\hline 8400 & 1962.451 & 2310.348 & 2646.438 & 3465.523 \\
\hline 5200 & 1566.039 & 2317.288 & 2508.267 & 3475.933 \\
\hline 2000 & 1691.523 & 2317.387 & 2460.222 & 3476.294 \\
\hline 0 & 1691.523 & 2317.387 & 2460.222 & 3476.294 \\
\hline
\end{tabular}




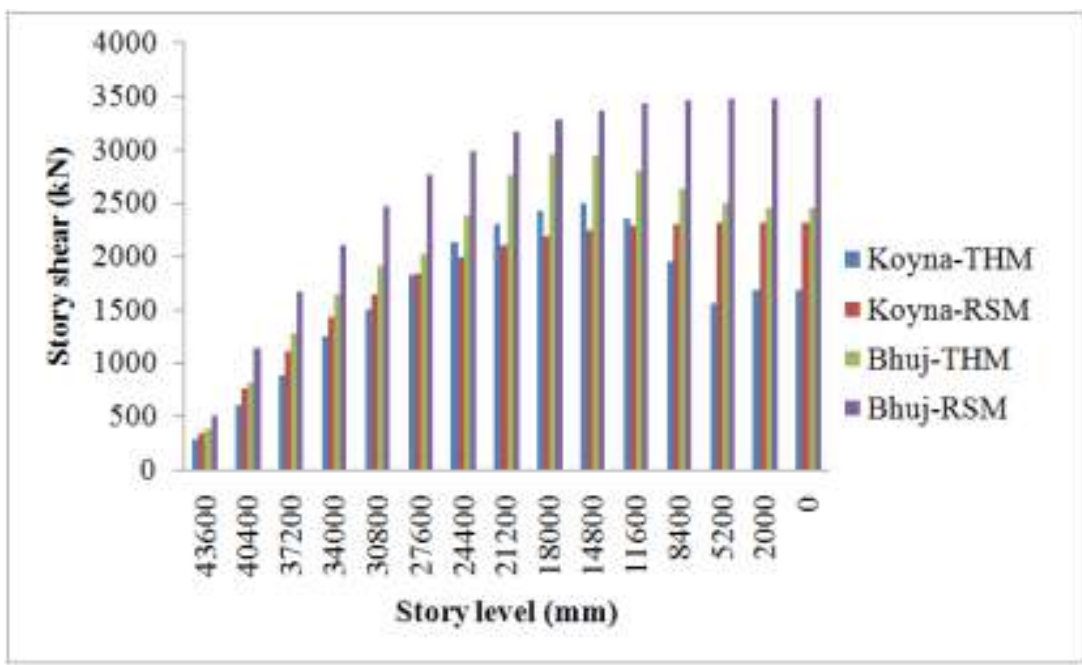

Fig. 2 Comparison of Base Shear for Koyna\&Bhuj Earthquake by THM\&RSM

By Time History method base shear are 1691.523

$\mathrm{kN}$ for Koynaand forBhuj $2460.222 \mathrm{kN}$ and by

Response Spectrum Method values of base shear are $2317.387 \mathrm{kN}$ for Koyna and $3476.294 \mathrm{kN}$ for Bhuj earthquake

\section{E. Storey Displacements:}

Table 2: Comparison of story displacement for earthquake by RSM and THM

\begin{tabular}{|l|l|l|l|l|}
\hline \multirow{2}{*}{$\begin{array}{l}\text { Story }(\mathrm{mm}) \\
0\end{array}$} & Stevel & Story displacement $(\mathrm{mm})$ & \multicolumn{4}{l|}{} \\
\cline { 2 - 5 } & Koyna-THM & Koyna-RSM & Bhuj-THM & Bhuj-RSM \\
\hline 0 & 0 & 0 & 0 & 0 \\
\hline 52000 & 0.681 & 0.734 & 0.492 & 1.102 \\
\hline 8400 & 3.077 & 3.527 & 2.451 & 5.291 \\
\hline 11600 & 5.497 & 6.653 & 4.732 & 9.982 \\
\hline 14800 & 7.714 & 9.707 & 7.038 & 14.562 \\
\hline 18000 & 9.415 & 12.623 & 9.252 & 18.901 \\
\hline 21200 & 11.589 & 15.304 & 11.291 & 22.957 \\
\hline 24400 & 13.503 & 17.819 & 14.017 & 26.717 \\
\hline 27600 & 15.198 & 20.115 & 17.484 & 30.174 \\
\hline 34000 & 16.898 & 22.209 & 20.939 & 33.315 \\
\hline 37200 & 20.063 & 25.691 & 27.404 & 38.538 \\
\hline 40400 & 21.187 & 27.012 & 29.980 & 40.521 \\
\hline 43600 & 21.347 & 28.004 & 31.827 & 42.009 \\
\hline
\end{tabular}

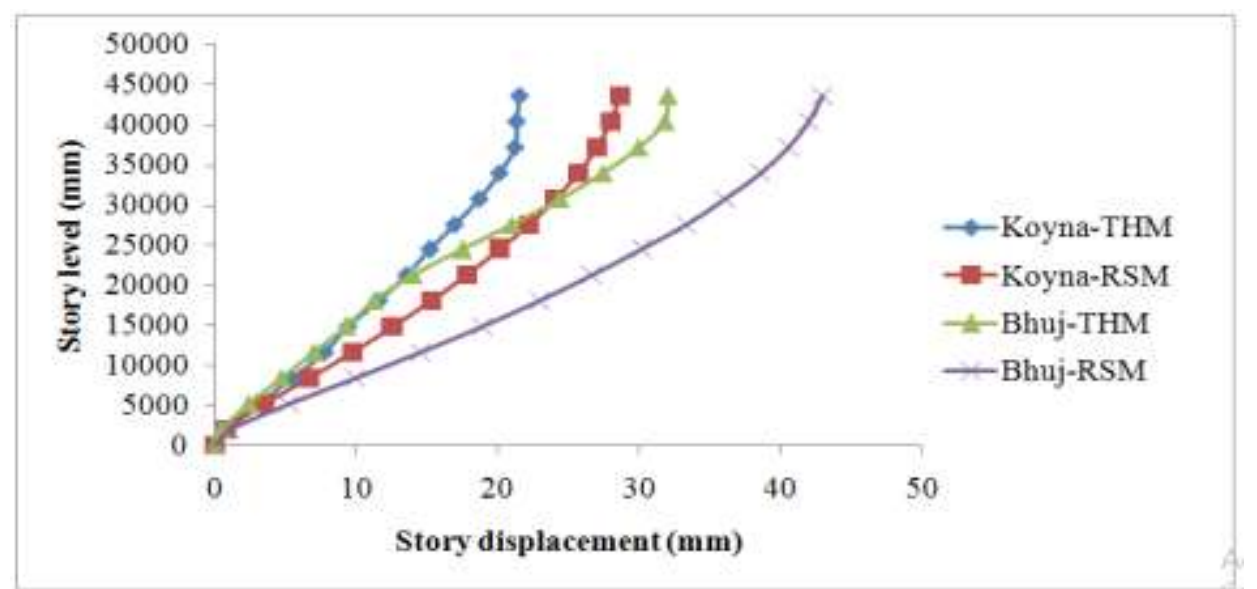

Fig. 3 Comparison of storey displacement for Earthquakes using RSM\&THM 
It has been observed that values of storey displacement are increases at top level from ground. From the graph it is observed that the value of displacements varies linearly for response spectrum analysis. The value of top storey displacements for Bhuj earthquake is $32.026 \mathrm{~mm}$ and forKoyna earthquake it is $21.528 \mathrm{~mm}$ by time history analysis.

\section{F. Storey Drift :}

As per clause no 7.11.1 of IS-1893 (Part-1) 2002 [7]: the storey drift in any storey due to specified design lateral force with partial load factor of 1 shall not exceed 0.004 times the storey height. Maximum storey drift for building $=0.004 \mathrm{X} \mathrm{h}$, for $3.2 \mathrm{~m}$ storey height it is $0.0128 \mathrm{~m}$.

Table 3: Variation of story drift for earthquake by RSM and THM

\begin{tabular}{|l|l|l|l|l|}
\hline \multirow{2}{*}{$\begin{array}{l}\text { Story } \\
(\mathrm{mm})\end{array}$} & Stevel & Story drift $(\mathrm{m})$ & \multicolumn{5}{|l|}{} \\
\cline { 2 - 5 } & Koyna-THM & Koyna-RSM & Bhuj-THM & Bhuj-RSM \\
\hline 0 & 0 & 0 & 0 & 0 \\
\hline 2000 & 0.000323 & 0.000734 & 0.000486 & 0.001102 \\
\hline 5200 & 0.001212 & 0.002793 & 0.001708 & 0.004189 \\
\hline 8400 & 0.001526 & 0.003126 & 0.002131 & 0.004689 \\
\hline 11600 & 0.001700 & 0.003054 & 0.002293 & 0.004582 \\
\hline 14800 & 0.001670 & 0.002893 & 0.002339 & 0.004339 \\
\hline 18000 & 0.001546 & 0.002704 & 0.002261 & 0.004056 \\
\hline 21200 & 0.001517 & 0.002506 & 0.002157 & 0.003763 \\
\hline 24400 & 0.001455 & 0.002305 & 0.002094 & 0.003457 \\
\hline 27600 & 0.001306 & 0.002094 & 0.002036 & 0.003141 \\
\hline 30800 & 0.001083 & 0.001868 & 0.001887 & 0.002802 \\
\hline 34000 & 0.000924 & 0.001613 & 0.001668 & 0.002421 \\
\hline 37200 & 0.000752 & 0.001322 & 0.001347 & 0.001983 \\
\hline 40400 & 0.000697 & 0.000992 & 0.001044 & 0.001488 \\
\hline 43600 & 0.000470 & 0.000661 & 0.000717 & 0.000992 \\
\hline
\end{tabular}

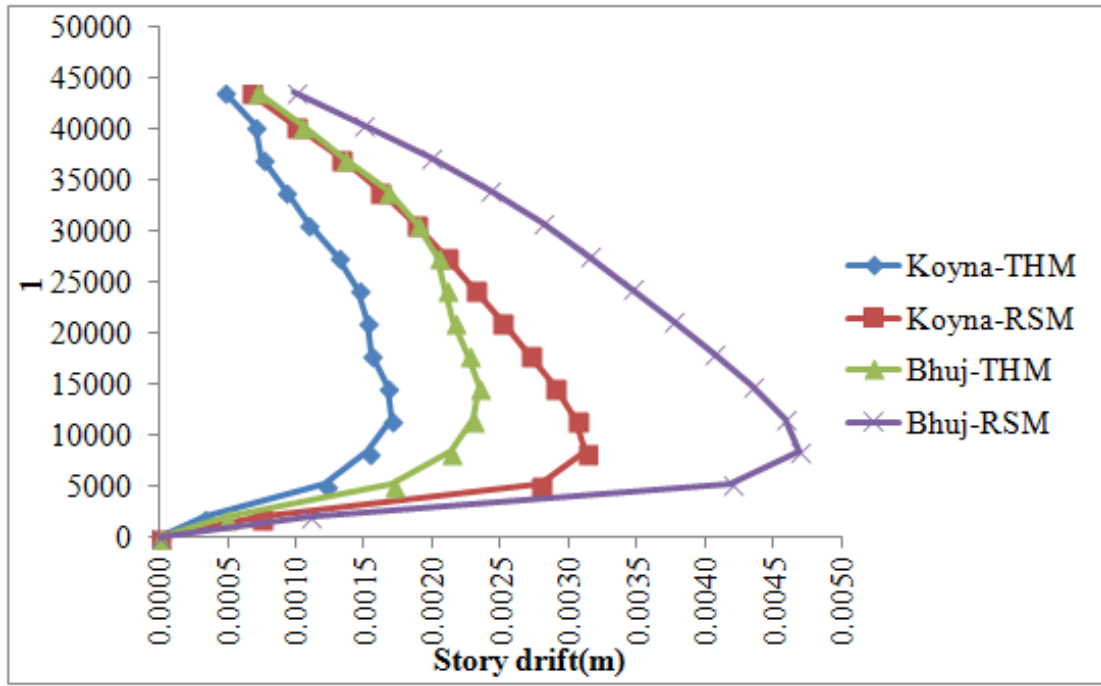

Fig. 4 Comparison of storey Drifts for Earthquakes using RSM\&THM

\section{G. Seismic loads on Building-}

The base shear force is calculated as per IS-1893(part-1) 2002 is given by

1) forKoyna $(Z=0.24)-$

$\mathrm{Z}=$ Zone factor $=0.24$

$\mathrm{I}=$ Importance factor $=1$

$\mathrm{R}=$ Response reduction factor $=5$

$\mathrm{Sa} / \mathrm{g}=1.06872$

$\mathrm{W}=$ Total seismic weight of the building
The dead load on each floor $=3.5 \mathrm{kN} / \mathrm{m}^{2}$

The Live load on each floor $=4 \mathrm{kN} / \mathrm{m}^{2}$

Total seismic load on the building $=88382.66 \mathrm{kN}$

$\mathrm{Vb}=(\mathrm{Z} / 2 \times \mathrm{I} / \mathrm{R} \times \mathrm{Sa} / \mathrm{g}) \times \mathrm{W}$

$=(0.24 / 2 \times 1 / 5 \times 1.06872)$

The Base Shear $=2272.30 \mathrm{KN}$ 


\section{2) For Bhuj ( $Z=0.36)$ -}

$\mathrm{Z}=$ Zone factor $=0.36$

$\mathrm{I}=$ Importance factor $=1$

$\mathrm{R}=$ Response reduction factor $=5$

$\mathrm{Sa} / \mathrm{g}=1.06872$

$\mathrm{W}=$ Total seismic weight of the building

The dead load on each floor $=3.5 \mathrm{kN} / \mathrm{m}^{2}$

\section{E. Pushover Analysis -}

The Pushover analysis is carried out as per the provisions in the ATC 40 and FEMA 356 using the software SAP 2000. The analysis result gives the actual performance of the building when subjected to the lateral earthquake loading.
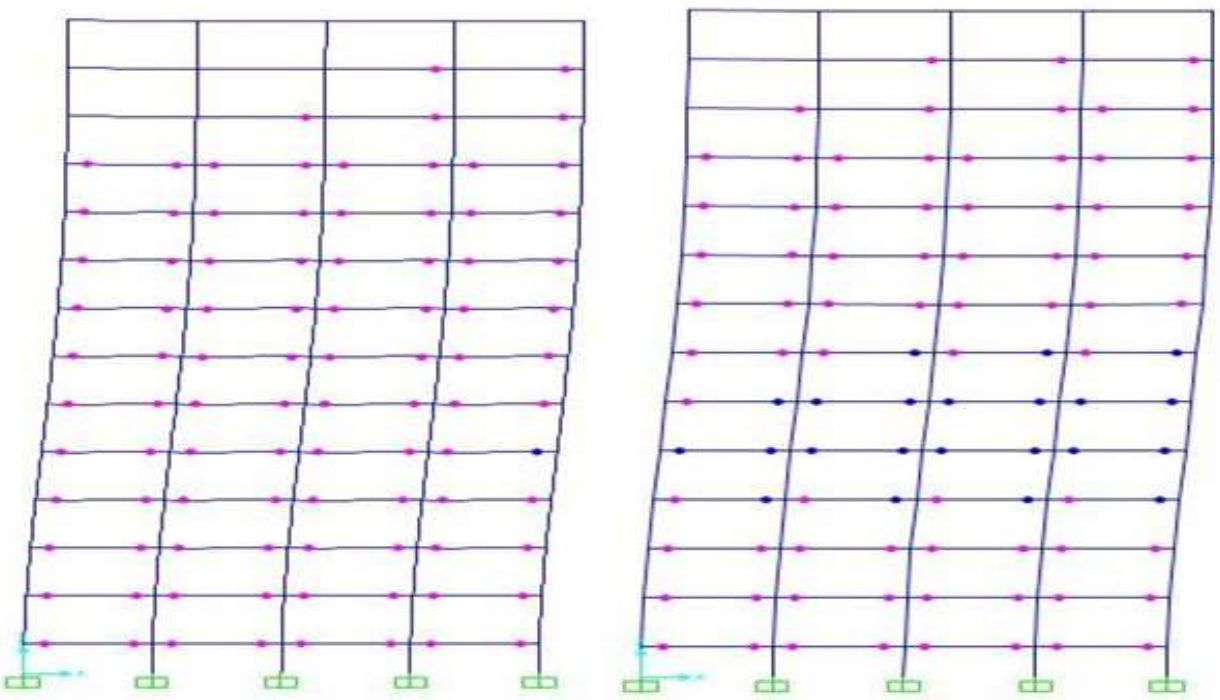

Fig. 5.Hinge formation at performance point for PUSH X for Koyna and Bhuj

\section{Capacity spectrum and the Performance} point -The performance of building in any
The Live load on each floor $=4 \mathrm{kN} / \mathrm{m}^{2}$

Total seismic load on the building $=88382.66 \mathrm{kN}$

$\mathrm{Vb}=(\mathrm{Z} / 2 \times \mathrm{I} / \mathrm{R} \times \mathrm{Sa} / \mathrm{g}) \times \mathrm{W}$

$=(0.36 / 2 \times 1 / 5 \times 1.06872)$

The Base Shear $=3409.12 \mathrm{kN}$

\section{Hinge formation}

As per the seismic requirement, the columns should be stronger than the beams. So the hinges should be formed in the beam first rather than in the columns. The figure below shows the hinge formation in the building frame.

earthquake can be assessed by superimposing the capacity diagram on the seismic demand diagram.

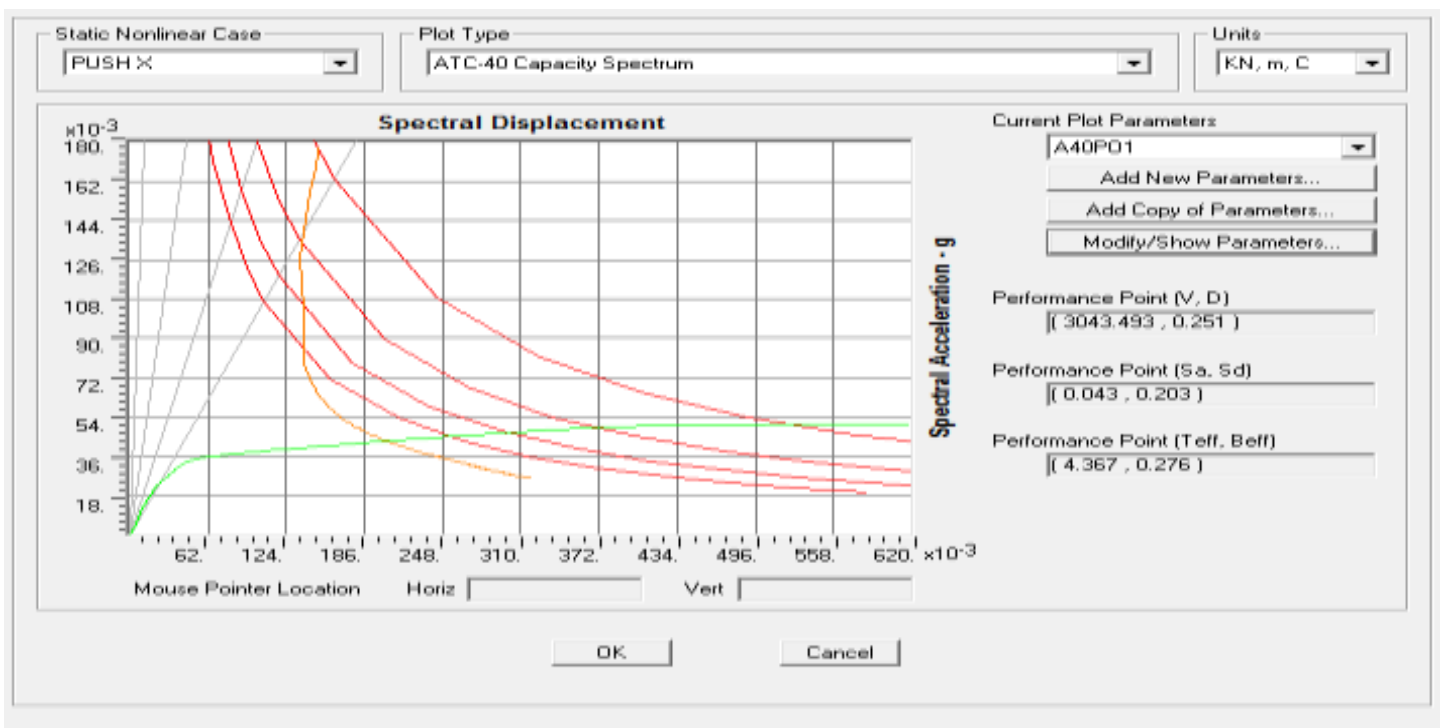

Fig. 6: Capacity spectrum of Koyna for PUSH X 


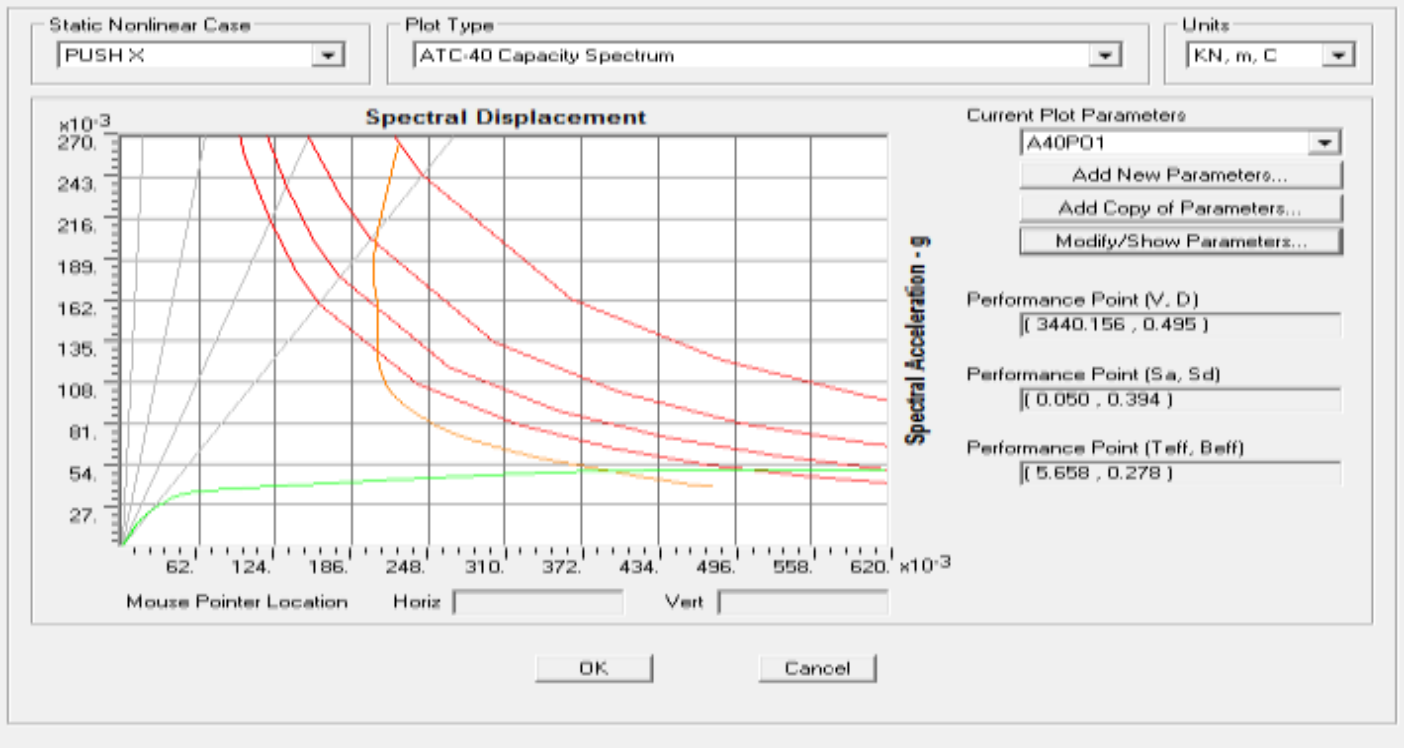

Fig. 7: Capacity spectrum of Bhuj for PUSH X

\section{G .Comparision Of Base Shear Result:}

Table 4:Comparison of Base shear

\begin{tabular}{|l|c|l|}
\hline Base shear(KN) & Manual calculation & Software result SAP2000 \\
\hline Bhuj & 3409.12 & 3476.294 \\
\hline Koyna & 2272.30 & 2317.387 \\
\hline
\end{tabular}

\section{CONCLUSION}

From the above results it is concluded that; 1]The seismic response such as base shear for Bhuj earthquake are found to be more by $45.44 \%$ than Koyna earthquake by using time history analysis. 2] The base shear of Koyna and Bhuj earthquake by response spectrum method is found to be $37.01 \%$ and $41.30 \%$ higher than time history method.

3] The top story displacement of Koyna and Bhuj earthquake by response spectrum method is found to be $33.15 \%$ and $34.26 \%$ higher than time history method.

4] The values of the storey drifts for all the stories for all the effects are found to be within the permissible limits specified as per IS: 1893-2002 (Part I).

5] From the results it is recommended that time history analysis should be performed as it predicts the Structural response more accurately than the response spectrum analysis.

6] From Table no.4 it is observed that Base shear results of SAP2000 software are found to be more by $1.92 \%$ than manually calculated base shear.

7] From figure no. 6 it is found that the hinges are found in the beams rather than columns which show the ductile behaviour of the frame.

8] It is concluded that building used for pushover analysis is seismically safe because performance point base shear is greater than design base shear for both koyna and Bhuj earthquakes.
9] The demand curve intersects the capacity curve near the elastic range; the structure has a good resistance and high safety against collapse.

\section{REFERENCES}

[1]. Patil A. S. and Kumbhar P. D. (2013), "Time History Analysis of Multistoried RCC Buildings for Different Seismic Intensities", International Journal of structural and civil engineering research, ISSN 2319 - 6009, Vol. 2, No. 3 pp. 194201.

[2]. Prashanth.P, Anshuman.S, Pandey.R.K, Arpan Herbert (2012), "Comparison of design results of a Structure designed using STAAD and ETABS Software", International Journal of Civil and Structural Engineering, ISSN 0976 4399, Volume 2, No 3.

[3]. Wakchaure M.R, Ped S. P (2012), "Earthquake Analysis of High Rise Building with and Without In filled Walls", International Journal of Engineering and Innovative Technology. ISSN: 2277-3754, Vol. 2, Issue 2. Page No. 89-94.

[4]. Mr.ParvathaneniSubash, Mr.S.Elavenil (2012), “Time History Response Prediction for Multi-Storey Buildings under Earthquake Ground Motions", Journal of Civil, Structural, Environmental, Water 
resources and Infrastructure Engineering Research Vol.2 ,Issue (2) pp 16-23

[5]. BahadorBagheri, EhsanSalimiFiroozabad, and MohammadrezaYahyaei (2012), "Comparative Study of the Static and Dynamic Analysis of Multi-Storey Irregular Building", World Academy of Science, Engineering and Technology. Vol.6. pp 1847-1851.

[6]. Bureau of Indian Standards (BIS). Plane and Reinforced Concrete Code of Practice, IS 456-2000 (Fourth Revision), New Delhi.

[7]. Bureau of Indian Standards (BIS). Criteria for Earthquake Resistant Design of Structures, IS 1893(Part I)-2002 (Fifth Revision), New Delhi.

[8]. Shrikhande M. and Agrawal P (2006), "Earthquake Resistant Design of Structures", First Revised Edition, PHI Learning Private Limited, New Delhi.

[9]. Md. Arman Chowdhury1, Wahid Hassan, "Comparative study of the Dynamic Analysis of Multi-storey Irregular building with or without Base Isolator", International Journal of Scientific Engineering and Technology, ISSN: 22771581, Volume No.2, Issue No.9, pp: 909912, Sept 2013.

[10]. MahammedYousuf and R.M.Shimpale "Dynamic analysis of Reinforced concrete buildings with plan irregularities". International Journal of Emerging technology and Advanced Engg.ISSN 2250-2459 ISO 9001:2008

[11]. Prof.Dr.Qaiseruz, Zaman khan "Evaluation of effect of Response spectrum Analysis on Height of Building'International conference (ICSBE-2010).

[12]. BhavinH.ZaveriJasminA.Gadhiya "Comparative study of steel, RCC and composite building'"'International Journal of Innovative Resarch in science Volume 05,1Jan2016 ISSN-2319-8753

[13]. Mahesh N. Patil, Yogesh N. Sonawane, "Seismic Analysis of Multistoried Building" from International Journal of Engineering and Innovative Technology (IJEIT), Volume 4, Issue 9, March 2015 ISSN: 2277-3754.

[14]. Wilkinson S and HileyR (2006), "A Non Linear Response Time History Model for theSeismic Analysis of High-Rise
FramedBuildings", Computers and Structures, Vol. 84.

[15]. Pravin B. Waghmare, P.S.Pajgade and N. M. Kanhe, Response spectrum analysis of a shear frame structure by using MATLAB, Int. Journal of Applied Sciences and Engineering Research, Vol. 1, No. 2, 20124

[16]. Patnala V S Neelima, RamancharlaPradeep Kumar, "Seismic Behaviour of RC Frame with URM Infill: A Case Study", International Journal of Education and applied research (IJEAR), Vol. 4, Issue Spl-2, Jan - June 2014 ISSN: 2348-0033 (Online) ISSN : 2249-4944 (IJERA), Vol. 3, Issue 4, Jul-Aug 2013, pp.176-185 ISSN: 2248-9622.

[17]. Sagar R Padol1, Rajashekhar S. Talikoti2 "Review paper on seismic responses of multistoredrcc building with mass irregularity review paper on seismic responses of multistoredrcc building with mass irregularity" IJRET: International Journal of Research in Engineering and Technology ISSN: 2319-1163 | ISSN: 2321-7308

[18]. Romy Mohan, C Prabha, "Dynamic Analysis of RCC Buildings with Shear Wall", International Journal of

[19]. Earth Sciences and Engineering ISSN 0974-5904,

[20]. Bhakti Narayan Harne1, Prof. R. R. Shinde, "Seismic Performance of MultiStoried RC Building with Soft Storey International Journal of Emerging Technology and Advanced Engineering, Volume 5, Issue 8, August 2015 ISSN 22

[21]. N.M .Nikam ,L.G.Kulkarnix "Pushover analysis of building with shear wall " IJESC- Volume -6 Issue no.6

[22]. Mohammad Azoz, Anshul R Nikhade "Pushover analysis of $\mathrm{G}+10$ Reinforced concrete structures for zone II and zone III as per IS1893(2002)".

[23]. Jyotipatil, dr.D.KKulkarni "Performance based evaluation of framed reinforced shear wall by pushover analysis"International journal of engineering and technology ISSN23950056 